A

$€$ Y

\title{
OPIEKA DUSZPASTERSKA W SZPITALACH PUBLICZNYCH PAŃSTW UNII EUROPEJSKIEJ - ZARYS PROBLEMATYKI
}

Duszpasterstwa specjalne, a zwłaszcza kwestia zaangażowania państwa w ich organizację, należą bez wątpienia do klasycznych zagadnień z zakresu prawa wyznaniowego. Nietrudno jednak dostrzec, że nie wszystkim z tych duszpasterstw towarzyszy podobnie intensywne zainteresowanie polskich autorów. Ze stosunkowo dużą liczbą prac dotyczących wolności praktyk religijnych żołnierzy i osób pozbawionych wolności, świadczonych wobec nich posług religijnych i odnoszących się do tego rozwiązań instytucjonalnych do niedawna kontrastowało zwłaszcza wyraźnie mniejsze zainteresowanie problematyką wolności religijnej pacjentów przebywających w szpitalach. Na zauważalną zmianę tego stanu wpłynęło ostatnio wydanie przez Sąd Najwyższy wyroku z dnia 20 września 2013 r. (II CSK 1/13) ${ }^{1}$, nadal

${ }^{*}$ Ks. dr hab. prof. KUL, Katedra Prawa Wyznaniowego, Wydział Prawa, Prawa Kanonicznego i Administracji, Katolicki Uniwersytet Lubelski Jana Pawła II, Al. Racławickie 14, 20-950 Lublin, e-mail: pstan@kul.pl

${ }^{1}$ Tekst wyroku: Przeglad Prawa Wyznaniowego 8 (2016): 199-211. Zob. Bartosz Rakoczy, „Glosa do wyroku Sądu Najwyższego z dnia 20 września 2013 r., sygn. akt II CSK 1/13", Przeglad Prawa Wyznaniowego 8 (2016): 213-220; Justyna Krzywkowska, Aleksandra Bitowt, „Poddanie człowieka nieakceptowanym przez niego praktykom religijnym”, w: Aktualne problemy wolności myśli, sumienia i religii, red. Piotr Stanisz, Aneta Abramowicz, Michał Czelny, Marta Ordon, Michał Zawiślak (Lublin: Wydawnictwo KUL, 2015), 191-203; Piotr Wenski, „Rozważania nad standardami opieki duszpasterskiej w polskich szpitalach. Uwagi na tle orzeczenia SN z 20 września 2013 r.”, Prawo i Medycyna 1 (2015): 
jednak brakuje odnoszących się do tej problematyki aktualnych opracowań o charakterze kompleksowym. Takiego charakteru nie ma również niniejsze opracowanie. Jego celem jest jedynie dokonanie generalnej charakterystyki rozwiązań, które w różnych państwach Unii Europejskiej wykorzystywane są dla zagwarantowania pacjentom prawa do korzystania z posług religijnych. W pierwszej części opracowania przedstawione zostanie uzasadnienie obecności zorganizowanej opieki duszpasterskiej w szpitalach. Następnie uwaga zostanie przeniesiona na kwestie związane z organizacją duszpasterstwa szpitalnego oraz ze statusem kapelanów szpitalnych. Całość zamknie zasygnalizowanie problemów związanych z ochroną negatywnej wolności religijnej pacjentów $^{2}$.

72-86; Wojciech Brzozowski, "When anointing becomes annoying: remarks on the Polish Supreme Court's Judgement of 20 september 2013 (II CSK 1/13)", Wroclaw Review of Law, Administration and Economics 5/2 (2015): 70-80.

${ }^{2}$ Niniejszy tekst jest przetłumaczoną i rozszerzoną wersją raportu (pt. Religious assistance in hospitals) zaprezentowanego podczas konferencji dotyczącej opieki religijnej w instytucjach publicznych (Religious assistance in public institutions) i zorganizowanej przez Europejskie Konsorcjum do Badania Stosunków Kościół - Państwo (European Consortium for Church and State Research), która odbyła się w miejscowości Jūrmala (Łotwa) w dniach 13-15 października 2016 r. Opracowanie zostało przygotowane na podstawie raportów krajowych sporządzonych przed konferencją przez autorów z poszczególnych państw Unii Europejskiej (Austria - Wolfgang Wieshaider, Belgia - Jogchum Vrielink i Adriaan Overbeeke, Chorwacja - Vanja Ivan Savić, Cypr - Achilles C. Emilianides, Czechy - Jiří Rajmund Tretera i Záboj Horák, Estonia - Merilin Kiviorg, Finlandia - Matti Kotiranta, Francja Francis Messner, Brigitte Basdevant-Gaudemet i Pierre-Henri Prélot, Grecja - Konstantinos Papageorgiou i Lina Papadopoulou, Hiszpania - Agustín Motilla, Holandia - Ryan van Eijk, Irlandia - Stephen Farrell, Litwa - Donatas Glodenis, Luksemburg - Philippe Poirier, Łotwa - Ringolds Balodis, Niemcy - Matthias Pulte, Polska - Piotr Stanisz, Portugalia - Jónatas E.M. Machado, Rumunia - Emanuel Tăvăla, Słowenia - Blaž Ivanc, Szwecja - Lars Friedner, Węgry - Balázs Schanda, Wielka Brytania - Frank Cranmer i Norman Doe, Włochy - Roberto Mazzola). Z racji praktycznych, nazwiska autorów tych raportów przywoływane są w niniejszym tekście jedynie w przypadku dosłownego cytowania. Zrezygnowano też z powtarzania szczegółowych opisów i miejsc publikacji aktów normatywnych, orzeczeń sądowych i innych źródeł. Wszelkie tłumaczenia, jeśli nie wskazano inaczej, pochodzą od autora i są oparte na wersjach angielskich zawartych w raportach stanowiących podstawę niniejszego opracowania. Raporty krajowe, które opracowano w związku z konferencją, podobnie jak i przedstawione w jej trakcie raporty generalne, są przygotowywane do druku w serii publikacji pokonferencyjnych Konsorcjum (zob. www.churchstate.eu). 


\section{UZASADNIENIE PRAWA DO POSŁUG RELIGIJNYCH W SZPITALACH}

\section{A. WOLNOŚĆ RELIGIJNA PACJENTÓW I PERSONELU}

Lektura raportów krajowych potwierdza intuicyjną tezę, zgodnie z którą zasadniczej podstawy obecności zorganizowanej opieki religijnej w szpitalach (podobnie jak np. w wojsku czy więzieniach) należy upatrywać w wolności religijnej należnej każdemu człowiekowi. Jak powszechnie wiadomo, wolność ta (abstrahując od pewnego zróżnicowania sformułowań używanych na jej określenie) gwarantowana jest nie tylko w systemach prawnych poszczególnych państw demokratycznych (a szczególnie w każdym z państw członkowskich Unii Europejskiej). Obowiązek jej poszanowania wynika również z różnorodnych umów międzynarodowych poświęconych ochronie praw człowieka.

Teoretyczna refleksja nad strukturą omawianej wolności prowadzi do wniosku, że prawo do opieki duszpasterskiej stanowi jej integralny składnik. Pomimo tego, w ustawach zasadniczych niektórych państw europejskich jest ono wyraźnie zagwarantowane. W Konstytucji Rzeczypospolitej Polskiej z 1997 r. stanowi się wyraźnie: „Wolność religii obejmuje także [...] prawo osób do korzystania z pomocy religijnej tam, gdzie się znajdują" (art. 53 ust. 2 in fine). Prawo do posług religijnych, przysługujące osobom przebywającym $\mathrm{w}$ takich placówkach jak szpitale, często jest ponadto wyraźnie gwarantowane w ustawach (nie tylko z zakresu prawa wyznaniowego, ale i z zakresu ochrony zdrowia) oraz w konkordatach, lub w obu rodzajach aktów jednocześnie. Na przykład w portugalskiej ustawie o wolności religijnej z 2001 r. stanowi się, że przebywanie w szpitalach lub podobnych instytucjach nie stoi na przeszkodzie korzystaniu z wolności religijnej, a w szczególności realizowaniu prawa do opieki duszpasterskiej i wykonywaniu aktów kultu. Jednocześnie na instytucje państwowe nałożony został obowiązek stworzenia właściwych warunków dla sprawowania opieki religijnej w takich instytucjach. Osobne gwarancje zawarto również w portugalskim Konkordacie z 2004 r. Z podobną sytuacją mamy do czynienia na przykład w Słowenii.

W normalnych warunkach zagwarantowanie możliwości korzystania z prawa do korzystania $\mathrm{z}$ opieki duszpasterskiej wymaga od 
państwa jedynie powstrzymania się od ingerencji dotyczącej możliwości jego realizacji. W świecie demokratycznym, pomijając sytuacje o charakterze wyjątkowym, próby ograniczania tego prawa właściwie się zresztą nie zdarzają. Nie jest też jednak tak, że państwa europejskie zupełnie nie znają prób arbitralnego ingerowania $\mathrm{w}$ to prawo, w tym również $\mathrm{w}$ odniesieniu do szpitali. $\mathrm{Z}$ tego typu ograniczeniami mieliśmy do czynienia w nieodległej przeszłości na przykład w państwach tzw. demokracji ludowej.

Powstają jednak sytuacje, gdy realne zagwarantowanie możliwości korzystania z prawa do opieki duszpasterskiej przez jednostkę wymaga zaangażowania ze strony państwa, po którego stronie powstają określone obowiązki pozytywne. W raporcie portugalskim trafnie zwrócono uwagę, że ,państwo nie tylko powinno się powstrzymać od naruszania tego prawa, ale ma również pozytywny obowiązek tworzenia normatywnych, instytucjonalnych i organizacyjnych warunków, które są potrzebne do jego ochrony i realizacji; dotyczy to zwłaszcza tych sytuacji, w których negatywny obowiązek [nieingerencji - przyp. PS] nie wystarcza do zagwarantowania omawianego prawa" (Jónatas E.M. Machado). Z tego typu sytuacją mamy do czynienia w przypadku szpitali. Należy się więc zgodzić z twierdzeniem, że „ochrona prawa do manifestowania wierzeń religijnych [...] musi z pewnością implikować obowiązek zapewnienia osobom, które nie dysponują wolnością poruszania się lub dysponują nią w ograniczonym stopniu, racjonalnej możliwości manifestowania religii. Odpowiednie struktury duszpasterskie składają się na taką możliwość” (Frank Cranmer i Norman Doe), albo też - innymi słowy - że ,zapewnienie opieki religijnej w formie zorganizowanego duszpasterstwa jest [a w każdym razie powinno być - przyp. PS] w określonych okolicznościach uważane za integralny element pozytywnych obowiązków państwa w odniesieniu do wolności religii, w szczególności należnej pacjentom szpitali oraz więźniom" (Jogchum Vrielink i Adrian Overbeeke). W podobnym duchu wypowiedział się również Sąd Najwyższy w Madrycie, który ponadto wskazał przesłanki warunkujące powstanie pozytywnych obowiązków obciążających państwo. W wyroku z 13 września 1999 r. sąd ten wyraził opinię, że ,tylko w sytuacji takiej potrzeby lub trudności jednostki, w której obywatel nie jest w stanie samodzielnie zaspokoić swoich potrzeb 
religijnych, zabezpieczenie możliwości ich realizacji w ramach jakiegoś modelu ustanowionego odgórnie staje się obowiązkiem państwa" (Agustín Motilla).

W raporcie brytyjskim sformułowano katalog racji uzasadniających istnienie zorganizowanych duszpasterstw specjalistycznych. Można go uznać za skondensowane ujęcie treści obecnych też w innych raportach. Na pierwszym miejscu wymieniono w nim zamknięty charakter określonej grupy, skutkujący ograniczeniem osób do niej należących w dostępie do posług religijnych świadczonych przez związki wyznaniowe w normalnym trybie. Na drugim miejscu umieszczono specyfikę danej grupy, wymagającą szczególnego rodzaju posługi duchowej. Rację tworzenia zorganizowanych duszpasterstw specjalistycznych dostrzeżono również $\mathrm{w}$ ułatwianiu wewnętrznej komunikacji poprzez istnienie niezależnej i konstruktywnej obecności w szczególnym, zazwyczaj hierarchicznie uporządkowanym kontekście. Uznając ten katalog za słuszny należy stwierdzić, że w przypadku szpitali wszystkie te racje występują.

Wyprowadzając wnioski z przeprowadzonych rozważań należy stwierdzić, że gwarancje prawa duchownych do swobodnego wstępu na teren szpitali na życzenie chorego stanowią absolutne minimum. Jak wynika z raportów, to minimum jest zagwarantowane we wszystkich państwach Unii Europejskiej.

\section{B. WOLNOŚĆ RELIGIJNA W WYMIARZE WSPÓLNOTOWYM}

I INSTYTUCJONALNYM

Przystępując do omówienia prawa związków wyznaniowych do świadczenia opieki duszpasterskiej w szpitalach należy w pierwszej kolejności odwołać się do samoświadomości tychże wspólnot. Przekonanie o konieczności pomocy ludziom znajdującym się w szczególnie trudnej sytuacji życiowej stanowi bowiem jeden z centralnych elementów tożsamości wielu związków wyznaniowych. Dotyczy to zwłaszcza - choć przecież nie wyłącznie - z jednej strony wyznań chrześcijańskich, a z drugiej - osób dotkniętych chorobą czy niedołężnością. Wystarczy w tym miejscu przypomnieć słowa Chrystusowe z Ewange- 
lii według św. Mateusza (25, 31-46). Poziom wrażliwości na potrzeby chorych jest tu ujęty wśród kilku kryteriów, które mają być uwzględnione w czasie Sądu Ostatecznego.

W kilku raportach zwraca się uwagę na to, że pierwsze szpitale były w państwach europejskich zakładane i prowadzone przez instytucje religijne (nie tylko chrześcijańskie, ale też na przykład żydowskie) bądź przynajmniej z religijnej inspiracji. Jest jasne, że w takich sytuacjach troska o chorego nie ograniczała się do wymiaru cielesnego. Szczególnie wymowne jest w tym zakresie brzmienie skandynawskich dokumentów kościelnych z XIII-XV wieku, w których podkreślono kapłański obowiązek posługi wobec chorych i umierających, ustanawiając nawet kary dla duchownych, którzy tego obowiązku nie realizowali w sposób właściwy. Tak więc, jak słusznie podkreśla Matthias Pulte, ,posługa religijna w szpitalach bądź domach opieki jest klasycznym zadaniem wyznań chrześcijańskich, zgodnie z przesłaniem biblijnym". Tezę tę można rozciągnąć na wiele innych wspólnot religijnych.

Prawo związków wyznaniowych do realizowania opieki duszpasterskiej w takich instytucjach jak szpitale, w niektórych państwach jest wyraźnie gwarantowane na poziomie ustaw zasadniczych. Jako przykład można podać (nadal pozostający w mocy) art. 141 Konstytucji Weimarskiej z 1919 r., zgodnie z którym „w razie zapotrzebowania na nabożeństwa i służbę duszpasterską w szpitalach, zakładach karnych i innych instytucjach publicznych, należy zezwolić związkom wyznaniowym na sprawowanie czynności religijnych, przy czym zakazany jest jakikolwiek przymus"3. Podobne unormowania zawarte są w Konstytucji Rumunii z 1991 r., zgodnie z którą ,wyznania religijne są niezależne od państwa i korzystają z jego pomocy, włącznie z ułatwianiem wsparcia religijnego w wojsku, w szpitalach, w zakładach karnych, w domach starców i w sierocińcach" (art. 29 ust. 5) ${ }^{4}$. W innych państwach analogiczne gwarancje odnajdujemy zazwyczaj

${ }^{3}$ Za: Konstytucja Niemiec, tłum. Bogusław Banaszak i Agnieszka Malicka (Warszawa: Wydawnictwo Sejmowe, 2008).

${ }^{4}$ Za: Konstytucja Rumunii, thum. Andrzej Cosma (Warszawa: Wydawnictwo Sejmowe, 1996). 
na poziomie ustawowym lub w umowach państwowo-kościelnych (a zwłaszcza w konkordatach).

\section{OPIEKA DUCHOWA JAKO INTEGRALNY ELEMENT OPIEKI ZDROWOTNEJ}

Lektura raportów krajowych pozwala na zidentyfikowanie jeszcze jednego uzasadnienia dla opieki religijnej w szpitalach. Niektórzy autorzy słusznie zwracają uwagę, że zorganizowania takiej opieki wymaga kompleksowo postrzegana troska o pacjenta. Takie stwierdzenia znalazły się na przykład w raporcie pt. „Rząd, religia i przekonania” (Government, religion and life convictions), który został przygotowany przez specjalną komisję powołaną przez holenderski rząd w 1988 r. „Komisja doszła do wniosku, że opieka duchowa powinna stanowić część zabezpieczonego, podstawowego pakietu świadczeń opieki zdrowotnej oraz że jej finansowanie nie wymaga osobnego zaangażowania rządowego". Już wcześniej, w 1972 r. Narodowa Rada Szpitali (National Council of Hospitals) zadeklarowała, że ,opieka duchowa stanowi integralny element opieki szpitalnej” (Ryan van Eijk).

\section{PRAWO DO OPIEKI DUSZPASTERSKIEJ W SZPITALACH JAKO EUROPEJSKI STANDARD}

Podsumowując tę część raportu należy zgodzić się z Normanem Doe, który formułując zasady prawa wyznaniowego wspólne wszystkim państwom europejskim wskazuje m.in., że ,każda osoba ma prawo do swobodnego praktykowania religii w szpitalach [...], a państwo jest zobowiązane do ustanowienia w tym celu stosownych regulacji” oraz że „osoby pełniące funkcje religijne mogą pełnić obowiązki duszpasterskie wobec pacjentów" "Zapewnienie prawa do opieki duszpasterskiej każdej osobie można uznać za europejski standard, którego realizacja nie zależy do przyjętego modelu relacji Państwo - Kościół. Od

${ }^{5}$ Norman Doe, Law and Religion in Europe: A Comparative Introduction (Oxford: Oxford University Press, 2011), 264. 
tego modelu zależeć może natomiast sposób, w jaki zabezpieczone jest wykonywanie tego prawa. Świadczy o tym wymownie wyrok słoweńskiego Sądu Konstytucyjnego z 2010 r., w którym uznano, że ,zatrudnienie duchownych lub asystentów religijnych, pełniących posługi jako kapelani, przez szpitale publiczne [...] jako urzędników publicznych [...] narusza konstytucyjną zasadę separacji”. Personel religijny nie może być więc zatrudniany w słoweńskich szpitalach w takim charakterze, „może jednak otrzymywać wynagrodzenie za wykonywaną pracę" (Blaž Ivanc).

\section{ORGANIZACJA DUSZPASTERSTWA W SZPITALACH}

A. PODMIOTY I OKOLICZNOŚCI DECYDUJĄCE O KSZTAŁCIE DUSZPASTERSTWA SZPITALNEGO

Sposób organizacji duszpasterstwa w szpitalach jest zróżnicowany i zmienia się w zależności od państwa. W „Standardach Duszpasterstwa Służby Zdrowia w Europie" (Standards for Health Care Chaplaincy in Europe), opracowanych przez Europejską Sieć Duszpasterstwa Ochrony Zdrowia (European Network of Health Care Chaplaincy) podczas konsultacji w Finlandii w 2002 r. stwierdzono, że forma omawianego duszpasterstwa zależy od samych grup religijnych, instytucji ochrony zdrowia, państwowych regulacji i polityk z zakresu ochrony zdrowia oraz stowarzyszeń kapelańskich ${ }^{6}$.

Raporty krajowe zasadniczo potwierdzają te spostrzeżenia. Na przykład w Belgii czy w Portugalii kwestie dotyczące duszpasterstwa w szpitalach zostały dość szczegółowo uregulowane w państwowych aktach normatywnych (nie tylko na poziomie ustaw czy ewentualnie konkordatów, ale i w aktach wykonawczych). Dość często jednakże w przepisach państwowych gwarantuje się jedynie prawo pacjenta do opieki religijnej i związane z tym prawo wspólnot religijnych do organizowania takiej opieki. Natomiast określenie sposobu realizowania tych

${ }^{6}$ Tekst na stronie internetowej Europejskiej Sieci Duszpasterstwa Ochrony Zdrowia (www.enhcc.eu). 
praw należy do władz lokalnych bądź nawet do zarządów szpitali (które to podmioty są często wyraźnie zobowiązane do działania w porozumieniu z władzami związków wyznaniowych, jak to jest na przykład we Włoszech). Natomiast w takich państwach, jak Szwecja czy Finlandia, organizację duszpasterstwa w szpitalach pozostawia się związkom wyznaniowym. Z kolei na Łotwie sporą rolę w tym zakresie odgrywają nie tylko wspólnoty religijne, ale i Stowarzyszenie Łotewskich Zawodowych Kapelanów Ochrony Zdrowia (Association of Latvian Professional Health Care Chaplains).

Przedstawiona systematyka podmiotów mających wpływ na organizację duszpasterstwa szpitalnego wymaga jednak podkreślenia roli państwa jako gwaranta należytego zabezpieczenia praw należnych jednostkom. Wydaje się, że od państwa należy oczekiwać pewnego minimum regulacji, zależnego od istniejącej świadomości społecznej. Konsekwencje braku takich regulacji widać na przykładzie Łotwy, gdzie organizacja omawianego duszpasterstwa w praktyce „zależy od zrozumienia i dobrej woli osób kierujących państwowymi instytucjami i placówkami" (Ringolds Balodis). W konsekwencji, w przypadku tego państwa możliwe jest wyróżnienie trzech grup szpitali. Na pierwszym miejscu należy wymienić szpitale z wyposażonymi kaplicami oraz kapelanami należącymi do grona pracowników. W drugiej grupie są szpitale z wyposażonymi kaplicami, ale bez kapelanów. Natomiast trzecią grupę tworzą szpitale bez kaplic i bez kapelanów.

Jeśli chodzi o okoliczności, które decydują o sposobie organizacji duszpasterstwa szpitalnego, należy wymienić przede wszystkim cztery czynniki: strukturę wyznaniową danego społeczeństwa, ukształtowane tradycje, aplikowany model relacji Państwo - Kościół oraz zróżnicowanie form regulacji sytuacji prawnej związków wyznaniowych. Kształt tego duszpasterstwa (podobnie jak np. duszpasterstwa wojskowego czy więziennego) wciąż przynajmniej w pewnej mierze zależy od tego, jak zostało ono ukształtowane w przeszłości. W państwach stosunkowo jednolitych wyznaniowo z natury rzeczy dominują struktury duszpasterskie Kościoła większościowego (Malta, Polska, Włochy, Cypr, Finlandia, Litwa, Rumunia, itd.) i na nich skupia się nie tylko uwaga państwowego prawodawcy, ale zazwyczaj do nich też ogranicza się finansowe wsparcie ze strony państwa. Efekt ten jest dodatko- 
wo wzmocniony przez ewentualne istnienie formalnie ustanowionego Kościoła państwowego. Analogiczna sytuacja powstaje w systemie przewidującym istnienie religii uznanych. W Belgii w odniesieniu do religii uznanych (oraz zrównanego z nimi świeckiego humanizmu) wspierane przez państwo duszpasterstwo szpitalne organizowane jest na zasadach maksymalnego równouprawnienia. Jednak pozostałe religie i związki wyznaniowe (w tym również te, które posiadają licznych wyznawców) pozostają zupełnie poza systemem duszpasterstw wspieranych przez państwo. Szczególna sytuacja istnieje w Hiszpanii, gdzie można mówić o trzech różnych sposobach organizacji duszpasterstwa szpitalnego, w zależności od formy regulacji sytuacji prawnej danego związku wyznaniowego. Najbardziej rozbudowane i finansowane ze środków publicznych są struktury duszpasterstwa katolickiego. Stałe struktury (ale bez finansowania) posiadają też federacje religijne, które zawarły z państwem umowy o współpracy. Natomiast związki wyznaniowe wpisane do rejestru mają prawo sprawować opiekę religijną nad swoimi członkami, ale nie tylko bez wynagrodzenia, ale i bez stałych struktur.

Szczególne warunki dla funkcjonowania duszpasterstwa w szpitalach istnieją w takich państwach, jak Estonia. Tylko niecałe 30\% populacji deklaruje tam przynależność do jakiegoś związku wyznaniowego, natomiast ponad połowa Estończyków twierdzi, że ma własny, indywidualny system wierzeń, niezależny od jakiegokolwiek związku wyznaniowego. Tworzy to podatny grunt dla kwestionowania potrzeby ustrukturyzowanego duszpasterstwa w takich placówkach, jak szpitale. Skłania również do stawiania pytań dotyczących optymalnego modelu zabezpieczenia potrzeb pacjentów posiadających własny, indywidualny systemem wierzeń. O szczególnych warunkach funkcjonowania duszpasterstwa szpitalnego możemy mówić również w przypadku Irlandii, której społeczeństwo jest nadal mocno podzielone według kryterium wyznaniowego. Oczekiwanej współpracy między dwoma najważniejszymi tam Kościołami (a więc Kościołem Katolickim i Kościołem Anglikańskim) nie ma również w odniesieniu do szpitalnictwa. Spora część placówek ochrony zdrowia, tak jak w przeszłości, nadal należy do jednego z tych Kościołów, co decyduje o tożsamości placówki i realizowanym na jej terenie duszpasterstwie szpitalnym. 


\section{B. PODSTAWY PRAWNE}

Przenosząc uwagę na sposób uregulowania organizacji duszpasterstwa szpitalnego należy podkreślić przede wszystkim szerokie wykorzystywanie różnego rodzaju umów państwowo-kościelnych. Stosunkowo rzadko prawodawca państwowy decyduje się na szczegółowe uregulowanie tej kwestii bez odniesienia się do tego rodzaju umowy. Dużo częściej na poziomie ustaw gwarantuje się jedynie prawo pacjentów do otrzymywania posług religijnych oraz odpowiadające mu prawo związków wyznaniowych do ich realizowania. Natomiast zagadnienia szczegółowe są bardzo często określane w umowach.

Takie umowy bywają zawierane po pierwsze na szczeblu krajowym. Natomiast w umowach ze Stolicą Apostolską umieszcza się zazwyczaj jedynie generalne gwarancje praw należnych pacjentom i podmiotom kościelnym. Tak jest chociażby w przypadku Litwy. W umowie ze Stolicą Apostolską z 2000 r. przyjęto, że ustalenie szczegółów dotyczących realizacji prawa Kościoła Katolickiego do posług w szpitalach zostanie dokonane $\mathrm{w}$ drodze porozumienia między władzami litewskimi i właściwymi władzami kościelnymi. Na tej podstawie w 2002 r. zawarto umowę pomiędzy tamtejszą Konferencją Biskupów i Ministrem Zdrowia. Podobną umowę zawarł następnie Ewangelicki Kościół Reformowany. Tego rodzaju umowy państwowo-kościelne w sprawie posług religijnych w szpitalach i innych placówkach ochrony zdrowia obowiązują również na przykład w Chorwacji, Rumunii i Hiszpanii. Treść takich aktów wpływa następnie (chociaż niekiedy z pewnym opóźnieniem) na przepisy prawa państwowego, które mają powszechne zastosowanie.

Bardziej zdecentralizowany jest model, który znajduje zastosowanie we Włoszech. Przyjęto tam, że organizacja katolickiego duszpasterstwa szpitalnego ma być regulowana przez wewnętrzne regulacje szpitalne, wypracowane w porozumieniu z właściwym biskupem diecezjalnym. W praktyce, poszczególni biskupi występują zazwyczaj wspólnie w ramach regionalnych konferencji biskupów, które zawierają z właściwymi władzami poszczególnych regionów porozumienia na temat katolickiej opieki duszpasterskiej w podległych im szpitalach. 
Są wreszcie państwa, w których duszpasterstwo szpitalne jest regulowane $\mathrm{w}$ drodze porozumień państwowo-kościelnych dotyczących opieki religijnej w poszczególnych placówkach. Zgodnie z raportem maltańskim, organizacja opieki duszpasterskiej w dwóch najważniejszych instytucjach ochrony zdrowia jest tam określona w porozumieniach zawartych przez rząd oraz - odpowiednio - Zakon Braci Mniejszych Kapucynów i Archidiecezję Maltańską. Omawiane kwestie podobnie rozwiązywane są również na przykład w Czechach, gdzie wykorzystywany jest wzór umowy opracowany przez Czeską Konferencję Biskupów i Ekumeniczną Radę Kościołów.

Z ciekawą sytuacją mamy do czynienia w Anglii, gdzie obowiązek zorganizowania opieki duszpasterskiej przewidziany jest w kontraktach dotyczących realizowania świadczeń zdrowotnych, co uzupełniają rządowe wytyczne. Takie wytyczne decydują o kształcie duszpasterstwa szpitalnego również w Szkocji. Regulacje podustawowe odgrywają istotną rolę także na przykład w Słowenii (gdzie obowiązują ,Zasady dotyczące organizacji i wykonywania opieki duchowej w szpitalach i innych instytucjach ochrony zdrowia" - Rules on the organization and implementation of spiritual care in hospitals and other health care providers z 2008 r.), oraz w Portugalii (gdzie w mocy pozostają „Regulacje na temat Opieki Duchowej i Religijnej w Narodowej Służbie Zdrowia" - Regulation of Spiritual and Religious Care in the National Health Service z 2009 r.).

\section{ISTOTA DUSZPASTERSTWA SZPITALNEGO}

Z lektury raportów krajowych wynika, że wciąż dominuje tradycyjne pojmowanie istoty duszpasterstwa szpitalnego, jako formy zabezpieczenia potrzeb religijnych pacjentów i personelu, w szczególności poprzez umożliwienie im korzystania z posług religijnych oraz udziału w obrzędach religijnych, zgodnie z zasadami przyjmowanej przez nich religii. Klasycznymi duszpasterzami szpitalnymi są więc duchowni, a więc osoby uprawnione na zasadzie wyłączności do sprawowania niektórych świętych czynności. W tym ujęciu wsparcie psychologiczne jest - rzec można - efektem ubocznym; ważnym, ale nie pierwszo- 
planowym. Coraz częściej jednak udzielanie wsparcia psychologicznego w trudnej sytuacji choroby, czy tym bardziej bliskości śmierci, jest akcentowane osobno, jako cel równoważny ze sprawowaniem posług religijnych. Zgodnie z włoską ustawą z 1988 r. (nr 833) dotyczącą Narodowej Służby Zdrowia, cel posługi polegającej na opiece duszpasterskiej jest szeroki. Obok sprawowania kultu i udzielania sakramentów obejmuje ona psychologiczne wsparcie chorego oraz organizowanie aktywności o charakterze pastoralnym i kulturalnym. $\mathrm{Z}$ omawianą tendencją w niektórych państwach wiąże się wzrost liczby świeckich kapelanów szpitalnych udzielających raczej wsparcia psychologicznego, niż opieki duszpasterskiej rozumianej w tradycyjny sposób. Z tego typu sytuacją - jak należy sądzić - mamy do czynienia w Belgii, gdzie obok kapelanów w szpitalach pracują świeccy humanistyczni doradcy. W raporcie łotewskim wyrażono pogląd, że „sieć psychologów i pracowników socjalnych, obejmująca cały kraj i utrzymywana ze środków publicznych, przynajmniej w pewnym zakresie może być uważana za konkurencję dla duszpasterstwa" (Ringolds Balodis). Na inicjatywy mające na celu zorganizowanie systemowego wsparcia psychologiczno-duchowego dla osób niewierzących i agnostyków zwraca się uwagę również $\mathrm{w}$ raporcie włoskim.

Odnosząc się do zarysowanej wyżej kwestii trzeba przede wszystkim bez wątpliwości podkreślić, że wrażliwość na potrzeby psychologiczne (czy szerzej: duchowe) każdego człowieka, bez względu na jego światopogląd, jest godna najwyższego uznania. Pozostaje jednak pytanie o to, czy w przypadku prawa do opieki religijnej oraz prawa do wsparcia psychologicznego mamy do czynienia ze zjawiskami jednorodnymi, które powinny podlegać jednolitym regulacjom, czy też ze zjawiskami zróżnicowanymi, które mogą (a może wręcz powinny) podlegać uregulowaniom zróżnicowanym? W konsekwencji można postawić pytanie, czy organizacja obu rodzajów wsparcia pacjentów powinna być postrzegana na zasadzie alternatywy czy raczej komplementarności?

Dość szczególny rodzaj duszpasterstwa szpitalnego realizowany jest natomiast w Holandii. Placówki ochrony zdrowia są tam zobowiązane „do zapewnienia dostępności opieki duchowej w formie, która w najwyższym możliwym stopniu odpowiada religii lub przekonaniom 
egzystencjalnym pacjenta bądź klienta" (Ryan van Eijk). Nie musi to być więc opieka dokładnie odpowiadająca przekonaniom pacjenta. Autor raportu holenderskiego zwraca uwagę, że obecnie osoba udzielająca opieki duchowej niekoniecznie musi być kojarzona z określonym wyznaniem i często nie posiada aprobaty żadnych władz kościoła lub innego związku wyznaniowego. Jestem przekonany, że to rozwiązanie jest słusznie krytykowane przez autora raportu holenderskiego.

\section{KSZTAŁT STRUKTUR DUSZPASTERSTWA SZPITALNEGO}

Organizacja duszpasterstwa szpitalnego w różnych państwach dość istotnie się różni. Zróżnicowanie można dostrzec również w ramach poszczególnych państw: w różny sposób są mianowicie zorganizowane posługi duszpasterskie realizowane przez różne związki wyznaniowe.

Zatrzymajmy się najpierw na zróżnicowaniu, które można dostrzec pomiędzy różnymi państwami. Pierwszy model organizacji duszpasterstwa szpitalnego - najmniej angażujący dla państwa - polega właściwie jedynie na zagwarantowaniu wspólnotom religijnym nieskrępowanej możliwości objęcia opieką duszpasterską pacjentów i szpitalnego personelu (np. Węgry i Estonia). Zgodnie z tymi założeniami duszpasterstwo w szpitalach nie jest finansowane przez państwo, a organizacja tego duszpasterstwa jest pozostawiona związkom wyznaniowym. Mogą one wyznaczyć specjalnych kapelanów szpitalnych, mogą jednak również zdecydować, że wszyscy duchowni uczestniczą w opiece duszpasterskiej nad chorymi.

Trzeba zauważyć, że duszpasterstwo szpitalne częściej pozostaje formalnie niezorganizowane niż ma to miejsce w przypadku duszpasterstwa wojskowego czy więziennego. Częściej też nie ma państwowego finansowania. Na przykład w Estonii obowiązują szczegółowe regulacje dotyczące duszpasterstwa w wojsku i więzieniach, i w przypadku obu tych instytucji przewidziane jest finansowanie kapelanów z budżetu państwa, natomiast w przypadku duszpasterstwa szpitalnego brakuje zarówno formalnie ustanowionych struktur, jak i państwowego finansowania.

Drugi model organizacji duszpasterstwa szpitalnego polega na finansowaniu z funduszy publicznych kapelanów (z jednego lub kilku związ- 
ków wyznaniowych) realizujących posługi duszpasterskie w szpitalach. Dzieje się tak jednak pod warunkiem, że zostali oni wyznaczeni przez właściwe władze religijne i zaakceptowani przez dyrekcję określonej placówki bądź inne właściwe władze (Malta, Włochy, Polska, Belgia, etc.).

Trzeba wreszcie zaznaczyć, że w ramach danego państwa organizacja duszpasterstwa szpitalnego różni się często w zależności od związku wyznaniowego. Państwowe finansowanie, nawet tam, gdzie jest przewidziane, nigdy nie dotyczy wszystkich duchownych ze wszystkich związków wyznaniowych, zaangażowanych w zapewnianie pacjentom opieki religijnej. Tak więc obok istnienia duszpasterstwa ustrukturyzowanego i finansowanego przez państwo funkcjonuje zwykle również rozwiązanie, które dotyczy pozostałych grup religijnych i polega jedynie na przysługującym duchownym (lub innym osobom do tego wyznaczonym) prawie wstępu na teren szpitali na życzenie pacjenta. Zdarza się wreszcie nawet zróżnicowanie pomiędzy różnymi szpitalami. Na przykład na Litwie dyrekcje szpitali mogą zatrudniać kapelanów, ale nie mają takiego obowiązku. W związku z tym obok szpitali, w których są stali kapelani katoliccy są też szpitale, w których posługę bez wynagrodzenia pełnią lokalni duszpasterze.

\section{E. KAPLICE SZPITALNE}

Sytuacja jest zróżnicowana również jeśli chodzi o obecność kaplic w szpitalach. W państwach, w których mamy do czynienia ze społeczną dominacją jednego wyznania, powstają kaplice tego właśnie wyznania (np. Polska). W Portugalii regułą jest obligatoryjność istnienia w szpitalu stałej kaplicy katolickiej, która może być ewentualnie dzielona $\mathrm{z}$ innymi wyznaniami chrześcijańskimi. W niektórych państwach powstają jedynie wielowyznaniowe pokoje modlitwy lub kaplice ekumeniczne (np. Czechy), a w innych są one tworzone obok kaplic wyznania większościowego (np. Malta). Z kolei w Niemczech, pomimo braku obowiązku ustanawiania kaplic szpitalnych, w niektórych szpitalach funkcjonują nie tylko kaplice chrześcijańskie, ale również muzułmańskie i żydowskie pokoje modlitwy. Regułą jest przy tym, że kaplice 
są własnością instytucji goszczącej (szpitala), a ich funkcjonowanie jest finansowane ze środków tej placówki. Odstępstwa od tej zasady nie są liczne.

\section{STATUS KAPELANÓW}

\section{A. ZASADY WYZNACZANIA I ODWOŁYWANIA KAPELANÓW SZPITALNYCH} ORAZ STAWIANE IM WYMAGANIA

W cytowanych wyżej „Standardach Duszpasterstwa Służby Zdrowia w Europie" wskazuje się, że pełnienie posługi kapelańskiej wymaga profesjonalnego przygotowania, które obejmuje formację teologiczną i pastoralną, wiedzę na temat ochrony zdrowia, praktyczne doświadczenie kliniczne oraz kierownictwo duchowe. W zgodzie z tymi standardami, w niektórych państwach od kapelanów szpitalnych wyraźnie wymaga się zrealizowania specjalistycznego programu przygotowawczego oraz zaliczenia testu potwierdzającego posiadanie wymaganych kwalifikacji (Finlandia). Wymóg posiadania specjalnej formacji pastoralno-klinicznej stawiany jest również kapelanom w publicznych szpitalach Irlandii, chociaż formacja ta może być zastąpiona innym, równoważnym przygotowaniem (jak można sądzić, chodzi o przygotowanie seminaryjne). Każdy kto chce pracować jako kapelan rzymskokatolicki musi uzyskać certyfikat Zarządu Duszpasterstwa Służby Zdrowia (Healthcare Chaplaincy Board), który podlega Konferencji Biskupów Irlandii oraz Konferencji Przełożonych Zakonnych. Zgodnie z decyzją Kościoła Irlandii, obowiązek legitymowania się odpowiednią formacją pastoralno-kliniczną, analogiczną do tej wymaganej w Kościele Katolickim, mają spełniać również pełnoetatowi, świeccy kapelani tego Kościoła. W kierunku ustanowienia konieczności zdobycia ściśle określonych kwalifikacji przez kandydatów na kapelanów szpitalnych idzie też inicjatywa realizowana na Łotwie w jednym ze szpitali uniwersyteckich. Przygotowano tam profesjonalny przygotowawczy program pastoralno-kliniczny dla osób już pełniących lub przygotowujących się do pełnienia opieki duchowej w szpitalach. Jednak w większości państw do objęcia stanowiska kapelana szpital- 
nego wystarcza w zasadzie kościelna nominacja, której następstwem - jeśli kapelana z placówką ochrony zdrowia ma łączyć jakaś określona więź prawna - jest formalne ustanowienie kapelana przez dyrekcję danej placówki. Oceniając ten fakt trzeba wziąć pod uwagę, że w wielu wspólnotach religijnych (jak np. w Kościele Katolickim) formacja generalnie wymagana od kapłanów obejmuje właściwie niemal wszystkie elementy określone w ,Standardach Duszpasterstwa Służby Zdrowia w Europie" (poza poważniejszym, praktycznym przygotowaniem klinicznym).

W sytuacjach, w których kapelana nie łączy z placówką ochrony zdrowia żadna więź prawna, a jego prawa ograniczają się do swobodnego dostępu do chorych, dyrekcja takiej placówki nie uczestniczy zwykle w procedurze ustanawiania kapelana, co jest wyłączną prerogatywą władz danego związku wyznaniowego (lub nawet jest pozostawione inicjatywie samego duchownego, działającego na zasadzie wolontariusza). Tylko w niektórych państwach (jak w szczególności w Portugalii czy Hiszpanii) formalnej ,autoryzacji” podlegają również kapelani, którzy nie otrzymują wynagrodzenia i nie są pracownikami (w Portugalii otrzymują oni, podobnie jak ich współpracownicy, specjalne identyfikatory).

Zgodnie z przedstawionymi konstrukcjami, cofnięcie skierowania określonego duchownego (lub innej osoby) do pełnienia funkcji kapelana, dokonane przez władze jego związku wyznaniowego, powinno skutkować rozwiązaniem więzi prawnej łączącej go z placówką ochrony zdrowia. Formalne zagwarantowanie takiej konsekwencji cofnięcia skierowania - jak wynika z raportów - nie są jednak powszechne (jest tak np. w Hiszpanii oraz na Litwie).

W niektórych państwach władze publiczne i dyrekcje szpitali mają znikomy wpływ na wyznaczanie bądź odwoływanie kapelanów pomimo tego, że istnieje państwowe finansowanie duszpasterstwa szpitalnego. Tak jest na przykład na Malcie. Kapelani są wyznaczani bezpośrednio przez podmiot kościelny, który w umowie zobowiązał się do zabezpieczenia opieki duszpasterskiej w danej placówce.

Zupełnie szczególna sytuacja istnieje w Holandii, gdzie osoba sprawująca opiekę duchową nad pacjentami nie musi się legitymować kościelną aprobatą i jest wyznaczana na zasadach indywidual- 
nych przez podmiot realizujący świadczenia zdrowotne. Jak zauważono w raporcie holenderskim, rodzi to uzasadnione wątpliwości co do jakości zabezpieczonej w ten sposób opieki duchowej.

B. CHARAKTER STOSUNKU PRAWNEGO ŁĄCZĄCEGO KAPELANA ZE SZPITALEM I ZASADY WYNAGRADZANIA KAPELANÓW

Wyraźne zróżnicowanie dotyczy również statusu kapelanów szpitalnych oraz zasad ich wynagradzania. Najsilniejszą więź pomiędzy kapelanem i szpitalem tworzy nawiązanie stosunku pracy. Jako pracownik, zgodnie z zasadami prawa pracy, kapelan jest zobowiązany do wykonywania pracy ustalonej w umowie na zasadach podporządkowania dyrekcji szpitala, za co otrzymuje wynagrodzenie. To rozwiązanie stosowane jest w sytuacjach oczekiwanego od niego wysokiego poziomu zaangażowania ze względu na dużą liczbę pacjentów oczekujących jego posługi. Na przykład w litewskim rozporządzeniu Ministra Zdrowia z 2009 r. przyjęto, że kapelani mogą być zatrudniani przez szpitale, jeśli istnieje potrzeba zapewnienia stałej posługi duszpasterskiej.

Potrzeba pracowniczego zatrudnienia duchownego (bądź ewentualnie osoby świeckiej) na stanowisku kapelana odnosi się zazwyczaj do wspólnot religijnych socjologicznie dominujących w danym państwie bądź ewentualnie jakimś jego regionie. Rozwiązanie polegające na zatrudnianiu kapelanów na podstawie stosunku pracy wykorzystywane jest na przykład w Hiszpanii, Irlandii (w odniesieniu do duchownych katolickich), Polsce, Portugalii, Republice Czeskiej i w Rumunii. W niektórych państwach (jak na przykład Polska) kapelani wykonują niekiedy swoje funkcje również na podstawie umów cywilnoprawnych. Oczywiste jest przy tym, że również w krajach, w których kapelani są formalnie zatrudniani przez szpitale, pewna liczba duchownych i świeckich realizujących posługi duszpasterskie wobec pacjentów nie otrzymuje żadnego wynagrodzenia. Dotyczy to przede wszystkim osób należących do socjologicznie mniejszościowych grup religijnych, może mieć jednak zastosowanie również do tych, którzy należąc do wspólnot społecznie dominujących realizują posługi obok kapelanów formalnie zatrudnionych (na przykład we współpracy z nimi). 
Zdarzają się jednak państwa, w których kapelani szpitalni sprawują swoje funkcje bez jakichkolwiek formalnych umów. Więź prawna łącząca ich ze szpitalami jest wówczas bardzo słaba i ogranicza się właściwie do obowiązku przestrzegania reguł obowiązujących w danej placówce. Od szpitala, nad którego pacjentami rozciągają opiekę duszpasterską, nie otrzymują oni w szczególności żadnego wynagrodzenia. Kwestia ich utrzymania rozwiązywana jest zgodnie z zasadami obowiązującymi w danej wspólnocie religijnej.

Ze szczególną sytuacją mamy do czynienia w tych państwach, w których umowy dotyczące posług duszpasterskich zawierane są nie z poszczególnymi duchownymi, ale z jednostkami organizacyjnymi związków wyznaniowych (jak to się dzieje na przykład na Malcie). Chociaż $w$ ten sposób duszpasterstwo szpitalne jest finansowane z funduszy publicznych, to jednak stopień formalnego powiązania poszczególnych kapelanów ze szpitalami pozostaje niski. Podobnie jest również w przypadku Kościoła Anglikańskiego w Irlandii. Kościół ten każdego roku otrzymuje określoną kwotę (obecnie ok. 220.000 euro). W zamian jego duchowni w całym kraju są gotowi do tego, aby na wezwanie zrealizować posługę duszpasterską w pobliskim szpitalu. Do niedawna, duchowni kierujący parafiami, którzy ex officio obejmowali opieką szpitale położone na terenie ich parafii, otrzymywali za to niewielką kwotę z sumy wypłacanej Kościołowi przez państwo. Obecnie jednak Kościół Irlandii zaczął zatrudniać w pełnym wymiarze świeckich kapelanów, powierzając każdemu z nich dwa lub trzy szpitale. Oprócz tego posługi duszpasterskie w placówkach ochrony zdrowia są nadal pełnione przez duchownych parafialnych, którzy jednak nie otrzymują za to żadnego dodatkowego wynagrodzenia.

\section{DUSZPASTERSTWO SZPITALNE}

\section{A NEGATYWNA WOLNOŚĆ RELIGIJNA PACJENTÓW}

Analiza raportów krajowych prowadzi do wniosku, że jednym $\mathrm{z}$ najpoważniejszych problemów związanych $\mathrm{z}$ funkcjonowaniem duszpasterstw szpitalnych jest zapewnienie należnego poszanowania negatywnej wolności religijnej pacjentów, którzy nie wyznają żadnej 
religii, należą do mniejszości religijnych albo też mają indywidualnie zdefiniowany światopogląd. Jak twierdzi Vincent De Gaetano, „najpoważniejsze wyzwanie stojące w tym zakresie przed kapelanami stanowi praktyczna odpowiedź na pytanie o to, jak być widocznym i odpowiadać na potrzeby pacjentów bez naprzykrzania się rosnącej liczbie osób [...] które nie wyznają wiary religijnej”. Pośrednie potwierdzenie tej tezy może stanowić wyrok polskiego Sądu Najwyższego z 2013 r., w którym stwierdzono, że udzielenie przez katolickiego kapelana szpitalnego sakramentu namaszczenia chorych osobie niewierzącej bez jej zgody i wiedzy w czasie, w którym pozostawała ona w stanie śpiączki farmakologicznej, stanowi naruszenie swobody sumienia, rozumianej jako dobro osobiste i podlegającej ochronie na podstawie przepisów Kodeksu cywilnego.

Odnosząc się do tej kwestii należy się zgodzić z twierdzeniem, że wolność religijna jednostki bez wątpienia „obejmuje również przysługujące jej prawo do pozostania wolną od jakiejkolwiek opieki religijnej lub duchowej". Biorąc to pod uwagę należy stwierdzić, że państwo jest nie tylko zobowiązane do powstrzymania się od narzucania komukolwiek światopoglądu religijnego, ale także do ,ochrony jednostek przed niechcianym prozelityzmem, realizowanym przez inne (prywatne) jednostki" (Jogchum Vrielink i Adriaan Overbeeke).

Świadomość złożoności omawianej problematyki spowodowała, że w niektórych państwach wprowadzono szczegółowe unormowania, których celem jest zabezpieczenie pacjentów przed niechcianymi posługami. Poza Belgią, takie regulacje zostały opracowane również w Portugalii. Zostały one zawarte w przepisach z 2009 r. (Regulation of Spiritual and Religious Care in the National Health Service). Przyjęto w nich, że „o opiekę duchową i religijną powinien wyraźnie poprosić pacjent lub jego krewni bądź przyjaciele”. Preferuje się, aby odnosząca się do tego deklaracja została złożona w momencie przyjęcia pacjenta do szpitala, może być jednak złożona również w innym momencie. Z drugiej jednak strony wyraźnie przyjęto również, że taka opieka może zostać zainicjowana przez duchownego wspólnoty, do której pacjent należy, o ile ten się na to zgadza. Podkreślono jednocześnie, że żaden pacjent nie może być w żaden sposób poddawany presji, aby przyjął posługę religijną. Te same cele są realizowane przez szcze- 
gółowe wyliczenie w omawianym dokumencie praw przysługujących pacjentom oraz obowiązków obciążających kapelanów. Te pierwsze obejmują nie tylko prawo dostępu do posług z zakresu opieki duchowej i religijnej oraz udziału w aktach kultu religijnego, ale również prawo do bycia informowanym o zasadach sprawowania opieki religijnej, do odrzucenia posługi, o którą pacjent nie prosił oraz do poszanowania jego własnych przekonań. Natomiast wśród wyraźnie wymienionych obowiązków kapelanów znalazło się nie tylko realizowanie posług duszpasterskich, organizowanie aktów kultu religijnego i zachowywanie reguły poufności, ale także na przykład respekt wobec pacjentów, którzy nie życzą sobie opieki religijnej i uszanowanie podejmowanych przez nich decyzji.

Odnosząc się mutatis mutandis do wyroku Europejskiego Trybunału Praw Człowieka w sprawie Kokkinakis przeciwko Grecji można stwierdzić, że - patrząc na sprawę z perspektywy organizacji religijnych i kapelanów - istotne jest rozróżnienie pomiędzy dawaniem świadectwa, a więc ,prawdziwym ewangelizowaniem” (true evangelism) oraz „niestosownym prozelityzmem” (improper proselytism). Można się przy tym zgodzić z opinią, że ze względu na szczególną sytuację psychologiczną pacjentów, szpitale generalnie nie powinny być postrzegane jako ,pole działalności misjonarskiej” (Balázs Schanda), a brak zgody pacjenta stanowi granicę, której kapelan nie powinien przekraczać. Równocześnie trzeba jednak zwrócić uwagę na fakt, że w niektórych sytuacjach znalezienie rozwiązań nie budzących zupełnie żadnych wątpliwości może okazać się zadaniem niewykonalnym. Jako przykład można podać sytuację, w której wola pacjenta nie jest znana, ponieważ został przywieziony do szpitala w stanie zagrożenia życia i nieprzytomności, a poznanie woli członków jego rodziny, w krótkim czasie pozostającym na podjęcie decyzji o udzieleniu posługi religijnej, nie jest możliwe. $Z$ perspektywy duchownego trudno sobie wyobrazić powstrzymanie się w takich okolicznościach od zrealizowania posługi, której osoba niezdolna do zakomunikowania swej woli może bardzo potrzebować. 


\section{PODSUMOWANIE}

Zapewnienie prawa pacjentów do posług religijnych stanowi dziś uznany europejski standard. Różnią się natomiast szczegółowe gwarancje tego prawa. Zróżnicowanie dotyczy zwłaszcza organizacji duszpasterstwa szpitalnego oraz statusu kapelanów szpitalnych. Stosowane rozwiązania pozostają w zależności od takich czynników, jak wyznaniowa struktura społeczeństwa, ugruntowane tradycje, aplikowany model relacji Państwo - Kościół oraz zróżnicowanie form regulacji sytuacji prawnej związków wyznaniowych. Wśród problemów, które wciąż oczekują na satysfakcjonujące rozwiązania w sporej liczbie państw członkowskich Unii Europejskiej należy natomiast wymienić kwestię pełnej ochrony praw członków religii mniejszościowych oraz osób bez religijnej afiliacji. Chodzi przy tym o znalezienie takiego modelu, w którym należycie zharmonizowane byłyby prawa wszystkich, bez względu na ich przynależność do mniejszości czy większości.

\section{BIBLIOGRAFIA}

Balodis, Ringolds. "The Regulation and Organization of Chaplaincies in Latvia" (raport przygotowany na konferencję Religious assistance in public institutions, Jūrmala, 13-15 października 2016 r.).

Brzozowski, Wojciech. "When anointing becomes annoying: remarks on the Polish Supreme Court's Judgement of 20 september 2013 (II CSK 1/13)". Wroclaw Review of Law, Administration and Economics 5/2 (2015): 70-80. Cranmer, Frank, Norman Doe. "Chaplaincy and the law in the United Kingdom" (raport przygotowany na konferencję Religious assistance in public institutions, Jūrmala, 13-15 października 2016 r.).

Doe, Norman. Law and Religion in Europe: A Comparative Introduction. Oxford: Oxford University Press, 2011.

van Eijk, Ryan. "The Search for a workable balance: spiritual care in the Netherlands" (raport przygotowany na konferencję Religious assistance in public institutions, Jūrmala, 13-15 października 2016 r.).

Emilianides, Achilles C. "Chaplaincy and the law in Cyprus" (raport przygotowany na konferencję Religious assistance in public institutions, Jūrmala, 13-15 października 2016 r.). 
Farrell, Stephen. "Chaplaincy in Ireland" (raport przygotowany na konferencję Religious assistance in public institutions, Jūrmala, 13-15 października 2016 r.).

Friedner, Lars. "Chaplaincy - Sweden" (raport przygotowany na konferencję Religious assistance in public institutions, Jūrmala, 13-15 października 2016 r.).

Glodenis, Donatas. "Chaplaincy in the Republic of Lithuania" (raport przygotowany na konferencję Religious assistance in public institutions, Jūrmala, 13-15 października 2016 r.).

Ivanc, Blaž. "Religious assistance in public institutions - Slovenia" (raport przygotowany na konferencję Religious assistance in public institutions, Jūrmala, 13-15 października 2016 r.).

Kiviorg, Merilin. "Religious assistance in public institutions: Estonia" (raport przygotowany na konferencję Religious assistance in public institutions, Jūrmala, 13-15 października 2016 r.).

Kotiranta, Matti. "Religious assistance in public institutions: Finland" (raport przygotowany na konferencję Religious assistance in public institutions, Jūrmala, 13-15 października 2016 r.).

Krzywkowska, Justyna, Aleksandra Bitowt. „Poddanie człowieka nieakceptowanym przez niego praktykom religijnym". W: Aktualne problemy wolności myśli, sumienia i religii, red. Piotr Stanisz, Aneta Abramowicz, Michał Czelny, Marta Ordon, Michał Zawiślak, 191-203. Lublin: Wydawnictwo KUL, 2015.

Machado, Jónatas E.M. "Religious assistance in public institutions: the Portuguese case" (raport przygotowany na konferencję Religious assistance in public institutions, Jūrmala, 13-15 października 2016 r.).

Mazzola, Roberto. "Spiritual assistance in the Italian legal system" (raport przygotowany na konferencję Religious assistance in public institutions, Jūrmala, 13-15 października 2016 r.).

Messner, Francis, Brigitte Basdevant-Gaudemet, Pierre-Henri Prélot. "Assistance spirituelle en milieu clos" (raport przygotowany na konferencję Religious assistance in public institutions, Jūrmala, 13-15 października 2016 r.).

Motilla, Agustín. "Religious chaplaincy in Spain" (raport przygotowany na konferencję Religious assistance in public institutions, Jūrmala, 13-15 października 2016 r.).

Papageorgiou, Konstantinos, Lina Papadopoulou. "Spiritual assistance in public institutions. Report: Greece" (raport przygotowany na konferencję 
Religious assistance in public institutions, Jūrmala, 13-15 października 2016 r.).

Poirier, Philippe. "Assistance spirituelle: Luxemburg” (raport przygotowany na konferencję Religious assistance in public institutions, Jūrmala, 13-15 października 2016 r.).

Pulte, Matthias. "Religious assistance in public institutions. German National Report" (raport przygotowany na konferencję Religious assistance in public institutions, Jūrmala, 13-15 października 2016 r.).

Rakoczy, Bartosz. „Glosa do wyroku Sądu Najwyższego z dnia 20 września 2013 r., sygn. akt II CSK 1/13". Przeglad Prawa Wyznaniowego 8 (2016): 213-220.

Savić, Vanja I. "Report on chaplaincies in Croatia - legal and historical overview" (raport przygotowany na konferencję Religious assistance in public institutions, Jūrmala, 13-15 października 2016 r.).

Schanda, Balázs. "Chaplaincies in Hungary" (raport przygotowany na konferencję Religious assistance in public institutions, Jūrmala, 13-15 października 2016 r.).

Stanisz, Piotr. "Religious assistance in public institutions: Poland" (raport przygotowany na konferencję Religious assistance in public institutions, Jūrmala, 13-15 października 2016 r.).

Tăvăla, Emanuel. "Religious assistance in public sphere. Romanian report" (raport przygotowany na konferencję Religious assistance in public institutions, Jūrmala, 13-15 października 2016 r.).

Tretera, Jiří R., Záboj Horák. "Religious assistance in public institutions: Czech Republic" (raport przygotowany na konferencję Religious assistance in public institutions, Jūrmala, 13-15 października 2016 r.).

Vrielink, Jogchum, Adriaan Overbeeke. "Religious assistance in institutions: Belgium" (raport przygotowany na konferencję Religious assistance in public institutions, Jūrmala, 13-15 października 2016 r.).

Wenski, Piotr. „Rozważania nad standardami opieki duszpasterskiej w polskich szpitalach. Uwagi na tle orzeczenia SN z 20 września 2013 r.”. Prawo i Medycyna 1 (2015): 72-86.

Wieshaider, Wolfgang. "Les aumôneries dans des établissements public autrichiens" (raport przygotowany na konferencję Religious assistance in public institutions, Jūrmala, 13-15 października 2016 r.). 


\section{RELIGIOUS ASSISTANCE IN PUBLIC HOSPITALS \\ IN THE STATES OF THE EUROPEAN UNION \\ - AN OVERVIEW}

\section{Summary}

The aim of the paper is to provide a general characterization of the solutions used in the states of the European Union to guarantee free access to religious assistance in public hospitals. The first part presents the justification for such assistance. The organization of hospital chaplaincy and the status of hospital chaplains are discussed respectively in part 2 and 3 . The paper concludes with a discussion of the problems connected with the need to protect the negative religious freedom of patients.

The analysis leads to a conclusion that ensuring the right of every patient to religious assistance constitutes a recognized European standard, independently of the adopted model of state-church relations. However, the detailed guarantees of this right differ from state to state. The diversification characterizes both the organization of hospital chaplaincy and the status of chaplains. The relevant solutions are dependent on such circumstances as the religious structure of the society, established traditions, applied model of state-church relations and diversification of forms of regulating the legal situation of religious organizations. Among the problems which still need to be solved in a satisfactory way in a considerable number of European states one can mention the question of full protection of rights of religious minorities and persons without religious affiliation. However, the prospective guarantees of such protection should be fairly balanced with protecting the rights of believers belonging to sociologically dominant religions.

Ttumaczenie własne autora

Key words: hospital chaplaincy, hospital chaplain, religious assistance, religious freedom, freedom of conscience and religion, State-Church relations

Słowa kluczowe: duszpasterstwo szpitalne, kapelan szpitalny, posługi duszpasterskie, wolność religijna, wolność sumienia i wyznania, relacje Państwo - Kościół 